\title{
The kinin $B_{1}$ receptor antagonist SSR240612 reverses tactile and cold allodynia in an experimental rat model of insulin resistance
}

\author{
JP Dias ${ }^{1}$, MA Ismael ${ }^{1}$, M Pilon $^{1}, \mathrm{~J}$ de Champlain ${ }^{1}$, B Ferrari $^{2}$, P Carayon $^{2}$ and R Couture ${ }^{1}$ \\ ${ }^{1}$ Department of Physiology, Faculty of Medicine, Université de Montréal, Montréal, Québec, Canada and ${ }^{2}$ Sanofi-Aventis R\&D, \\ Montpellier, France
}

\begin{abstract}
Background and purpose: Diabetes causes sensory polyneuropathy with associated pain in the form of tactile allodynia and thermal hyperalgesia which are often intractable and resistant to current therapy. This study tested the beneficial effects of the non-peptide and orally active kinin $B_{1}$ receptor antagonist SSR240612 against tactile and cold allodynia in a rat model of insulin resistance.

Experimental approach: Rats were fed with 10\% D-glucose for 12 weeks and effects of orally administered SSR240612 (0.3$30 \mathrm{mg} \mathrm{kg}^{-1}$ ) were determined on the development of tactile and cold allodynia. Possible interference of SSR240612 with vascular oxidative stress and pancreatic function was also addressed.

Key results: Glucose-fed rats exhibited tactile and cold allodynia, increases in systolic blood pressure and higher plasma levels of insulin and glucose, at 12 weeks. SSR240612 blocked tactile and cold allodynia at $3 \mathrm{~h}\left(\mathrm{ID}_{50}=5.5\right.$ and $7.1 \mathrm{mg} \mathrm{kg}{ }^{-1}$, respectively) in glucose-fed rats but had no effect in control rats. The antagonist $\left(10 \mathrm{mg} \mathrm{kg}^{-1}\right)$ had no effect on plasma glucose and insulin, insulin resistance (HOMA index) and aortic superoxide anion production in glucose-fed rats.

Conclusions and implications: We provide the first evidence that the $B_{1}$ receptors are involved in allodynia in an experimental rat model of insulin resistance. Allodynia was alleviated by SSR240612 most likely through a direct inhibition of $B_{1}$ receptors affecting spinal cord and/or sensory nerve excitation. Thus, orally active non-peptide $\mathrm{B}_{1}$ receptor antagonists should have clinical therapeutic potential in the treatment of sensory polyneuropathy.
\end{abstract}

British Journal of Pharmacology (2007) 152, 280-287; doi:10.1038/sj.bjp.0707388; published online 9 July 2007

Keywords: kinins; bradykinin; $B_{1}$ receptor; diabetes mellitus; insulin resistance; allodynia; polyneuropathy; SSR240612

Abbreviations: BK, bradykinin

\section{Introduction}

The World Health Organization has estimated that there will be around 300 million patients with clinically diagnosed type II diabetes worldwide by the year 2025 (King et al., 1998; Gorus et al., 2004). The epidemic of diabetes is associated with a wide variety of long-term devastating macrovascular and microvascular complications that contribute to the increased mortality and morbidity (Feldman, 2003). Although several therapies are successfully used to control glycaemia with antidiabetic drugs and insulin, the major diabetic complications cannot be prevented and occur in $20-30 \%$ of type II diabetic patients which constitute $90 \%$ of the diabetic population (Feldman, 2003; Zimmet, 2003).

Correspondence: $\operatorname{Dr} \mathrm{R}$ Couture, Department of Physiology, Faculty of Medicine, Université de Montréal, C.P. 6128, Succursale Centre-ville, Montreal, Quebec, Canada H3C 3J7.

E-mail: rejean.couture@umontreal.ca

Received 29 March 2007; revised 13 June 2007; accepted 14 June 2007; published online 9 July 2007
Recent evidence suggests a link between hyperglycaemiainduced oxidative stress and the kinin $B_{1}$ receptor in the development of these clinical complications (Couture and Girolami, 2004; El Midaoui et al., 2005; Lungu et al., 2007).

Kinins are pro-inflammatory mediators of pain, which are also thought to be involved in the central autonomic control of blood pressure and nociception (Couture and Lindsey, 2000; Couture et al., 2001). These peptides acts on two G-protein-coupled receptors, a constitutive $B_{2}$ receptor and an inducible $B_{1}$ receptor. Bradykinin (BK) and Lys-BK or kallidin are the natural agonists for the prevailing $B_{2}$ receptors, while the kininase I metabolites des-Arg ${ }^{9}$-BK and des-Arg ${ }^{10}$-kallidin are the preferential agonists for $\mathrm{B}_{1}$ receptors (Regoli et al., 1998). The $B_{1}$ receptor is weakly expressed in healthy tissues and animals, but this receptor is upregulated and overexpressed in the presence of pro-inflammatory cytokines, bacterial endotoxins and hyperglycaemia-induced oxidative stress (Marceau et al., 1998; deBlois and Horlick, 2001; Couture and Girolami, 2004). A role was suggested for $\mathrm{B}_{1}$ receptors in vascular hyperpermeability, hyperalgesia, 
nephropathy, retinopathy, neuropathy and cardiovascular complications associated with type I diabetes (Cloutier and Couture, 2000; Campos et al., 2001, 2005; Mage et al., 2002; Simard et al., 2002; Abdouh et al., 2003; Gabra and Sirois 2003; Ongali et al., 2004; Lawson et al., 2005; Gabra et al., 2006). Recently, our laboratory reported an increased density of $B_{1}$ receptor binding sites in the brain, spinal cord and peripheral tissues of rats treated with glucose $(10 \%$ in drinking water) for a period of 4 and 12 weeks (El Midaoui et al., 2005; Lungu et al., 2007). This experimental rat model presents several hallmarks of type II diabetes such as greater plasma levels of glucose and insulin, arterial hypertension, insulin resistance and increases in the production of superoxide anion (marker of oxidative stress) in the heart and aorta (El Midaoui and de Champlain, 2002, 2005; El Midaoui et al., 2003, 2005). Further studies have shown sensory abnormalities, namely tactile and cold allodynia, after 4 weeks of treatment with glucose (Lungu et al., 2007).

The primary objective of this study was to determine whether the newly orally active non-peptide and selective $B_{1}$ receptor antagonist SSR240612 (Gougat et al., 2004) can reverse tactile and cold allodynia in glucose-fed rats, a model of insulin resistance. The possibility that the acute antiallodynic effect of SSR240612 could be attributed to a correction of pancreatic function or oxidative stress was also addressed.

\section{Methods}

\section{Animal model}

Young male Sprague-Dawley rats $(50-75 \mathrm{~g}$, Charles River, Quebec, Canada) were housed two per cage, under controlled conditions of temperature $\left(23^{\circ} \mathrm{C}\right)$ and humidity (50\%), on a $12 \mathrm{~h}$ light-dark cycle and allowed free access to normal chow diet (Charles River Rodent no. 5075) and tap water (control rats) or 10\% D-glucose (Sigma-Aldrich Canada, Oakville, Ontario, Canada) in the drinking water. All research procedures and the care of the animals were in compliance with the guiding principles for animal experimentation as enunciated by the Canadian Council on Animal Care and were approved by the Animal Care Committee of our University.

Systolic arterial blood pressure was measured by tail-cuff photoplethysmography (Harvard Apparatus Ltd, Kent, UK) and registered using MacLab/8 system. For each measurement, three individual readings were averaged (El Midaoui et al., 2005).

\section{Behavioural testing}

Behavioural signs representing tactile and cold allodynia were assessed with the rats placed on a wire mesh floor beneath an inverted plastic cage $(20 \times 10 \times 10 \mathrm{~cm})$. The rats were allowed to acclimatize for about $15 \mathrm{~min}$ or until explorative behaviour ceased.

\section{Tactile allodynia}

Tactile allodynia was assessed by measuring the hind pawwithdrawal threshold to a calibrated series of six von Frey filaments (2, 4, 6, 8, 10 and $15 \mathrm{~g}$ ) (Stoelting, Wood Dale, IL, USA) using the up-down method of Chaplan et al. (1994). Starting with the filament that has the lowest force $(2 \mathrm{~g})$, the filament was applied perpendicularly to the mid-plantar surface with sufficient force to cause the filament to buckle slightly. Brisk withdrawal or paw flinching was considered as positive response. Each filament was applied five times to each paw (for 6-8 s per stimulation, with an interstimulus interval of $1-2 \mathrm{~min})$. Minimum recording of five positive responses $(50 \%)$ out of 10 stimulations for both paws was considered to be the threshold (in grams). Absence of a response (less than five withdrawals) prompted use of the next graded filament of increasing weight. Maximal withdrawal threshold in control rats was fixed at $15 \mathrm{~g}$.

\section{Cold allodynia}

Cold allodynia was assessed using the acetone drop method described by Choi et al. (1994). With the rats under the same conditions of testing, an acetone bubble formed at the end of a standard plastic syringe was placed to the plantar surface of the hind paws. Acetone was applied five times to each paw at intervals of 3-5 min. Normal rats either ignore the stimulus or occasionally respond with a small and brief withdrawal. Allodynic rats respond with a prompt and intense paw withdrawal or escape behaviour to acetone application. The frequency of paw withdrawal was expressed as a percentage (the number of paw withdrawals/number of trials $\times 100$ ).

\section{Thermal hyperalgesia}

The development of thermal hypersensitivity associated with neuropathic pain was measured using the paw-withdrawal latency according to the method described by Hargreaves et al. (1988), with minor modifications. Rats were placed (not restrained) within a Plexiglass enclosure on a transparent glass floor and allowed to acclimatize for 20-30 min. An infrared beam that constitutes the noxious heat source was moved beneath the plantar surface of the hind paw. Thermal nociceptive threshold was defined as the latency (seconds) between the heat stimulus $\left(46^{\circ} \mathrm{C}\right)$ onset and the paw withdrawal using a feedback-controlled shutdown unit. A cut-off time of $33 \mathrm{~s}$ was used to avoid tissue damage. Each paw was tested three times alternatively at minimum intervals of $3 \mathrm{~min}$ between stimulation to avoid sensitization of the hind paw. Mean values of each paw were used as the thermal threshold.

Measurement of plasma glucose and insulin and insulin resistance At the end of protocol, overnight fasted rats were anaesthetized with $\mathrm{CO}_{2}$ inhalation and blood was rapidly collected from cut carotid arteries and immediately transferred into a chilled tube containing no more than $10 \mathrm{IU}$ heparin per $\mathrm{ml}$ of blood collected (Thorell and Lanner, 1973). The plasma was separated from blood cells by centrifugation and kept frozen at $-20^{\circ} \mathrm{C}$ for the later measurement of glucose with a glucometer (Elite, Bayer Inc., Toronto, Canada) and insulin by radioimmunoassay (rat insulin RIA kit, Linco Research, St Charles, MO, USA) using $100 \mu$ l of plasma. The Homeostasis Model Assessment 
(HOMA) was used as an index of insulin resistance and calculated with the following formula: (insulin $\left(\mu \mathrm{Uml}^{-1}\right) \times$ glucose (mM)/22.5) (Matthews et al., 1985).

\section{Superoxide anion measurement}

Superoxide anion production was measured in isolated thoracic aortic rings using the lucigenin-enhanced chemiluminescence method as described previously (Munzel et al., 1995). Briefly, 2-5 mg aortic tissue were pre-incubated in Krebs-HEPES buffer (saturated with 95\% $\mathrm{O}_{2}$ and 5\% $\mathrm{CO}_{2}$, at room temperature during $30 \mathrm{~min}$ ) and then transferred to a glass scintillation vial containing $5 \mu \mathrm{M}$ lucigenin for the determination of basal $\mathrm{O}_{2}^{-}$levels. The chemiluminescence was recorded in duplicate every minute for $6 \mathrm{~min}$ at room temperature by a liquid scintillation counter (Wallac 1409, Turku, Finland). Background counts were determined from vessel-free incubation media and subtracted from the readings obtained with vessels. Lucigenin counts were expressed as c.p.m. $\mathrm{mg}^{-1}$ of dry weight of tissue.

\section{Experimental protocols}

Effect of orally administered SSR240612 on allodynia. SSR240612 was administered orally to rats fed D-glucose for 12 weeks, which displayed consistent symptoms of sensory abnormalities. The effects of four doses $(0.3,3.0,10$ and $30 \mathrm{mg} \mathrm{kg}^{-1}$ ) of SSR240612 were determined on allodynia at 1 , $3,6,24$, and $48 \mathrm{~h}$ post-gavage. Values were compared to baseline values (time 0 ) measured on three subsequent days beforehand and to vehicle values. A single dose of $B_{1}$ receptor antagonist was randomly administered to a rat and the experimenter was unaware of the dose of antagonist.

Rats were randomly divided into five groups as follows: Group $1(n=6)$ : Glucose + vehicle; Group $2(n=6)$ : glucose + SSR240612 $\left(0.3 \mathrm{mg} \mathrm{kg}^{-1}\right)$; Group $3(n=12)$ : glucose + SSR240612 $\left(3.0 \mathrm{mg} \mathrm{kg}^{-1}\right)$; Group $4(n=13)$ : glucose + SSR240612 (10 $\left.\mathrm{mg} \mathrm{kg}^{-1}\right) ;$ Group $5 \quad(n=11)$ : glucose + SSR240612 (30 $\left.\mathrm{mg} \mathrm{kg}^{-1}\right)$. SSR240612 was also administered to two groups of age-matched controls rats at the dose of $10 \mathrm{mg} \mathrm{kg}^{-1}(n=6)$ and $30 \mathrm{mg} \mathrm{kg}^{-1}(n=6)$ and the impact on sensory threshold to tactile and cold stimulation was measured at 1, 3, 6, 24 and $48 \mathrm{~h}$ post-gavage.

Effect of orally administered SSR240612 on pancreas function and oxidative stress. SSR240612 was administered orally at the dose of $10 \mathrm{mg} \mathrm{kg}^{-1}$ to rats treated for 12 weeks with glucose $(n=8)$. Rats were fasted overnight and killed by $\mathrm{CO}_{2}$ asphyxia at $6 \mathrm{~h}$ post-gavage, and then the blood and thoracic aorta were collected for the measurement of plasma levels of glucose and insulin and the determination of superoxide anion, respectively. Data were compared to age-matched control rats $(n=8)$ and glucose-fed rats treated with the vehicle by gavage $6 \mathrm{~h}$ earlier $(n=8)$. Blood pressure and allodynia were measured in those rats the preceding day to ascertain that glucose-fed rats displayed hypertension and allodynia.

\section{Statistical analysis}

Data are expressed as mean \pm s.e.mean of values obtained from $n$ rats in each group. Statistical analysis of data and the doses of SSR240612, which inhibited allodynia by $50 \%$ $\left(\mathrm{ID}_{50}\right)$, were calculated with GraphPad Prism (version 4.00) software. $\mathrm{ID}_{50}$ value was determined from sigmoid doseresponse on maximal values with $95 \%$ confidence intervals. Statistical differences were evaluated with Student's $t$-test on unpaired (between groups) or paired (within the same group) samples. Multiple comparisons were analysed using one- or two-way analysis of variance (ANOVA), followed by the Bonferroni or Dunnett post-test accordingly. Probability values $(P)$ less than 0.05 were considered to be statistically significant.

\section{Drugs and reagents}

The selective non-peptide $\mathrm{B}_{1}$ receptor antagonist SSR240612 ((2R)-2-[((3R)-3-(1,3-benzodioxol-5-yl)-3-\{[(6-methoxy-2naphthyl)sulphonyl]amino\}propanoyl)amino]-3-(4-\{[(2R,6S)-2, 6-dimethylpiperidinyl]methyl\}phenyl)- $\mathrm{N}$-isopropyl- $\mathrm{N}$-methylpropanamide fumarate) (Gougat et al., 2004) was synthesized at Sanofi-Aventis R\&D (Montpellier, France). SSR240612 was dissolved in dimethylsulphoxide $(0.5 \%)$, and then ethanol (5\%) and Tween-80 (5\%) were added in this sequence. The solution was completed in distilled water. The drug was administered orally by gavage in a volume of $1 \mathrm{ml}$ by $100 \mathrm{~g}$ of body weight. D-Glucose was purchased from Sigma-Aldrich Canada.

\section{Results}

Baseline parameters in D-glucose-fed rats

As shown in Table 1, plasma levels of glucose and insulin as well as resting systolic blood pressure were significantly increased in rats fed with 10\% D-glucose for a period of 12 weeks when compared to age-matched control rats. However, the same treatment with D-glucose had no significant effect on the body weight. Data of Table 1 also show values of tactile and cold allodynia in glucose-fed rats when compared to baseline values obtained in control rats. The thermal nociceptive threshold as determined by the paw-withdrawal

Table 1 Baseline values in rats treated with glucose for 12 weeks

\begin{tabular}{|c|c|c|}
\hline Parameters & Glucose-fed rats & Control rats \\
\hline Weight (g) & $\begin{array}{c}501.9 \pm 6.4 \\
n=48\end{array}$ & $\begin{array}{c}535.4 \pm 23.5 \\
n=7\end{array}$ \\
\hline Plasma glucose $\left(\mathrm{mmoll}^{-1}\right)$ & $\begin{array}{c}6.2 \pm 0.3^{\star \star} \\
n=48\end{array}$ & $\begin{array}{c}4.1 \pm 0.2 \\
n=7\end{array}$ \\
\hline Plasma insulin $\left(\mathrm{ng} \mathrm{ml}^{-1}\right)$ & $\begin{array}{c}1.3 \pm 0.3^{\star \star *} \\
n=8\end{array}$ & $\begin{array}{c}0.40 \pm 0.06 \\
n=8\end{array}$ \\
\hline Systolic blood pressure $(\mathrm{mm} \mathrm{Hg})$ & $\begin{array}{c}155.7 \pm 1.6^{\star * *} \\
n=48\end{array}$ & $\begin{array}{c}124.6 \pm 4.8 \\
n=7\end{array}$ \\
\hline Tactile allodynia (g) & $\begin{array}{c}5.8 \pm 0.2^{\star \star *} \\
n=48\end{array}$ & $\begin{array}{c}11.4 \pm 1.1 \\
n=7\end{array}$ \\
\hline Cold allodynia (\%) & $\begin{array}{c}75.1 \pm 3.4^{\star * *} \\
n=48\end{array}$ & $\begin{array}{c}37.0 \pm 3.8 \\
n=7\end{array}$ \\
\hline Thermal nociception (s) & $\begin{array}{c}9.3 \pm 0.4 \\
n=30\end{array}$ & $\begin{array}{c}9.3 \pm 0.8 \\
n=7\end{array}$ \\
\hline
\end{tabular}

Values represent the mean \pm s.e.mean of $(n)$ rats. Statistical comparison to control rats is indicated by ${ }^{* *} P<0.01 ; * * * P<0.001$. 
reflex latency to a noxious thermal stimulus was not significantly different between 12 weeks glucose-fed rats and control rats (Table 1 ).

\section{Effect of orally administered SSR240612 on allodynia}

The oral administration of SSR240612 blocked dosedependently tactile allodynia $\left(\operatorname{ID}_{50}=5.5(4.0-7.6) \mathrm{mg} \mathrm{kg}^{-1}\right.$ ) in glucose-fed rats although the doses of $0.3 \mathrm{mg} \mathrm{kg}^{-1} \mathrm{did}$ not reach statistical significance (Figure 1). The dose of $3 \mathrm{mg} \mathrm{kg}^{-1}$ blocked at $3 \mathrm{~h}$ post-administration when compared to preadministration values only (paired Student's $t$-test). Doses of 10 and $30 \mathrm{mg} \mathrm{kg}^{-1}$ blocked tactile allodynia at $3 \mathrm{~h}$ when compared to vehicle values (two-way ANOVA and post-hoc Bonferroni test) or pre-administration values (paired Student's $t$-test) (Figures $1 \mathrm{a}$ and $\mathrm{b}$ ). At the highest dose of SSR240612, tactile allodynia was completely blocked and the paw-withdrawal threshold was not significantly different from that measured in control rats. In contrast, doses of 10 and $30 \mathrm{mg} \mathrm{kg}^{-1}$ SSR240612 did not affect paw-withdrawal threshold to tactile stimulation from 1 to $48 \mathrm{~h}$ postadministration in control rats when compared to preadministration values (Figure 1a). Cold allodynia was blocked by SSR240612 (ID $50=7.1\left(5.9-8.4 \mathrm{mg} \mathrm{kg}^{-1}\right.$ ) administered orally in glucose-fed rats (Figure 2). Doses of 10 and $30 \mathrm{mg} \mathrm{kg}^{-1}$ blocked significantly at $3 \mathrm{~h}$ when compared to vehicle values (two-way ANOVA and post-hoc Bonferroni test) and from 3 to $6 \mathrm{~h}$ and $1-24 \mathrm{~h}$ post-administration respectively when compared to pre-administration values (one-way ANOVA and post-hoc Dunnett test) (Figures 2a and b). Whereas the inhibition of cold allodynia did not seem to be complete at $30 \mathrm{mg} \mathrm{kg}^{-1}$, the residual response frequency was not significantly different from that measured in control rats at $3 \mathrm{~h}$ post-administration. In control rats, the
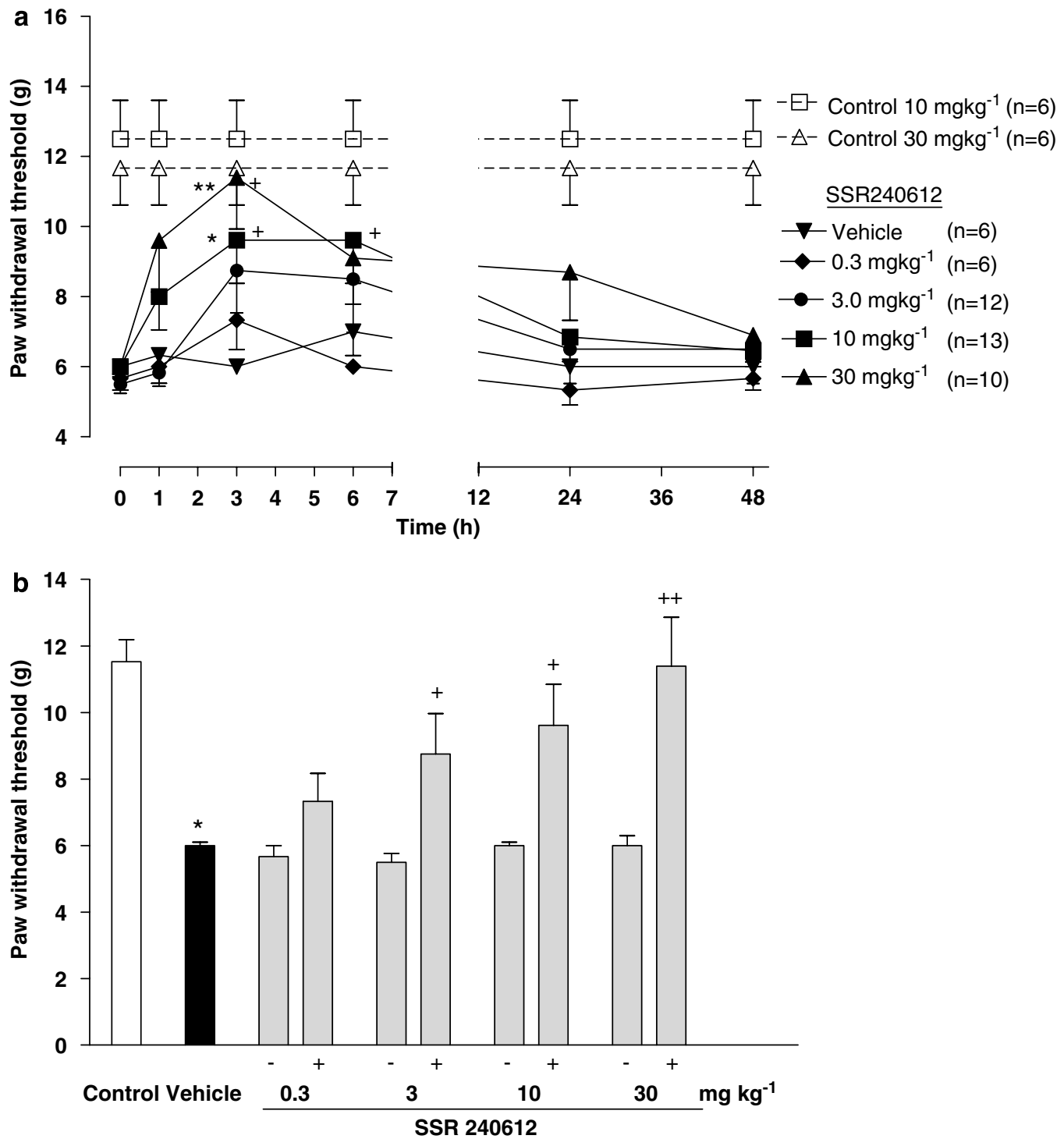

Figure 1 Time-course effect (a) and maximal effect (b) of SSR240612 (0.3, 3, 10 and $30 \mathrm{mg} \mathrm{kg}^{-1}$, p.o.) on tactile allodynia (paw-withdrawal threshold, in grams) in rats fed with glucose (10\% in drinking water) for 12 weeks. Effects of SSR240612 $\left(10\right.$ and $30 \mathrm{mg} \mathrm{kg}^{-1}$, p.o.) are also shown in age-matched control rats. Data are means \pm s.e.mean of $(n)$ rats in each group. Statistical comparison to vehicle $\left(^{*}\right.$ in a), control $\left({ }^{*}\right.$ in b) or pre-administration values (time 0$)(+)$ is indicated by ${ }^{*}+P<0.05 ;{ }^{* *}++P<0.01$. 

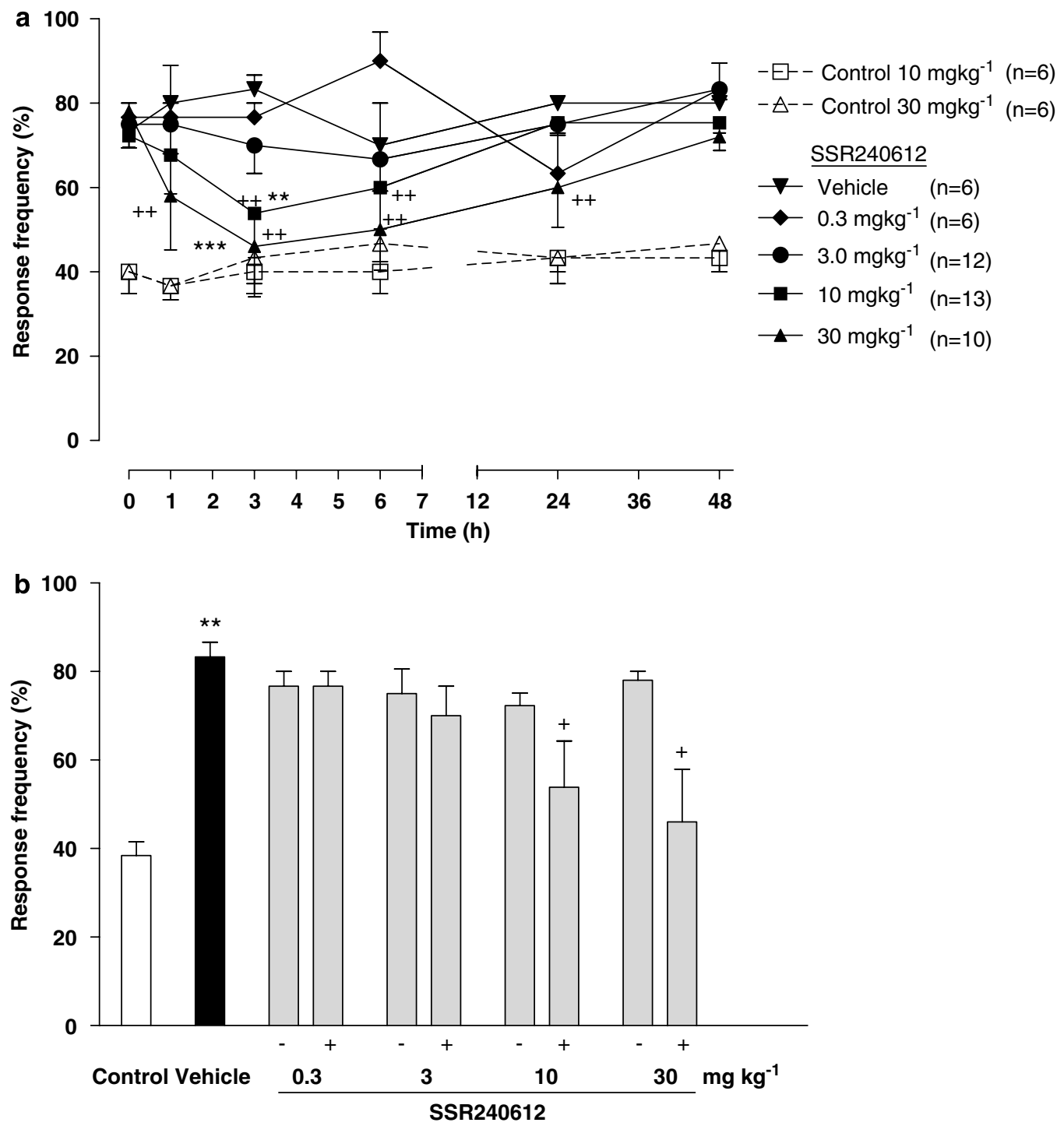

Figure 2 Time-course effect (a) and maximal effect (b) of SSR240612 (0.3, 3, 10 and $30 \mathrm{mg} \mathrm{kg}^{-1}$, p.o.) on cold allodynia (paw-withdrawal response frequency) in rats fed with glucose (10\% in drinking water) for 12 weeks. Effects of SSR240612 (10 and $30 \mathrm{mg} \mathrm{kg}^{-1}$, p.o.) are also shown in age-matched control rats. Data are means \pm s.e.mean of $(n)$ rats in each group. Statistical comparison to vehicle $\left({ }^{*}\right.$ in $\left.\mathbf{a}\right)$, control $\left({ }^{*}\right.$ in b) or pre-administration values (time 0$)(+)$ is indicated by $+P<0.05 ;++{ }^{* *} P<0.01 ;{ }^{* * *} P<0.001$.

administration of 10 and $30 \mathrm{mg} \mathrm{kg}^{-1}$ SSR240612 had no significant effect on the response frequency to cold stimulation (Figure 2a).

\section{Effect of orally administered SSR240612 on pancreas function} and oxidative stress

As shown in Table 2, plasma levels of glucose and insulin as well as insulin resistance (HOMA index) and the basal aortic superoxide anion production were significantly increased in glucose-fed rats in comparison with control rats. These values were not significantly affected when SSR240612 $\left(10 \mathrm{mg} \mathrm{kg}^{-1}\right)$ was given orally $6 \mathrm{~h}$ earlier.

\section{Discussion}

The present study strongly suggests a role for the inducible kinin $B_{1}$ receptor in glucose-induced allodynia, a manifesta- tion of sensory polyneuropathy. The $\mathrm{B}_{1}$ receptor antagonist SSR240612 is orally active and reversed dose- and timedependently tactile and cold allodynia in an experimental rat model of insulin resistance. Because the compound was found to be inactive on basal sensory function in control rats, we concluded that SSR240612 was not interfering with normal pain pathways and was not associated with nonspecific effects. The lack of effect of SSR240612 in control rats was consistent with the absence of $B_{1}$ receptors.

Earlier studies performed in glucose-fed rats for a period of 4 weeks have shown significant increases in systolic blood pressure and plasma levels of insulin and glucose along with insulin resistance, and an overproduction of basal superoxide anion in cardiovascular tissues (El Midaoui and de Champlain, 2002, 2005; El Midaoui et al., 2003, 2005). Tactile and cold allodynia occurred, however, after 4 weeks of treatment with glucose and arterial blood pressure was significantly higher at 12 weeks when compared to 4 weeks 
Table 2 Effects of SSR240612 (10 $\left.\mathrm{mg} \mathrm{kg}^{-1}\right)$ given orally $6 \mathrm{~h}$ before killing in rats treated with glucose for 12 weeks

\begin{tabular}{lccc}
\hline Parameters & Glucose-fed rats + vehicle, $\mathrm{n}=8$ & Glucose-fed rats + SSR240612, $\mathrm{n}=8$ & Control rats, $\mathrm{n}=8$ \\
\hline Plasma glucose $\left(\mathrm{mmoll}^{-1}\right)$ & $6.3 \pm 0.4^{* *}$ & $6.2 \pm 0.3^{* *}$ & $4.6 \pm 0.4$ \\
Plasma insulin $\left(\mathrm{ng} \mathrm{ml}^{-1}\right)$ & $1.7 \pm 0.5^{* * *}$ & $1.9 \pm 0.3^{* * *}$ & $0.6 \pm 0.07$ \\
HOMA index & $9.4 \pm 2.4^{* * *}$ & $10.6 \pm 1.8^{* * *}$ & $2.4 \pm 0.3$ \\
Aortic superoxide anion (c.p.m. $\left.\mathrm{mg}^{-1}\right)$ & $1500 \pm 91^{*}$ & $1537 \pm 106^{*}$ & $1239 \pm 36$ \\
\hline
\end{tabular}

Values represent the mean \pm s.e.mean of $(n)$ rats. Statistical comparison to control rats is indicated by ${ }^{*} P<0.05 ;{ }^{* *} P<0.01 ;{ }^{* *} P<0.001$.

of treatment (Lungu et al., 2007). The present study confirms the elevation of arterial blood pressure and the occurrence of allodynia at 12 weeks. Our data in glucose-fed rats are consistent with the values of arterial hypertension generally measured in patients and animal models of types II diabetes (Hwang et al., 1987; Dai and McNeill, 1995; Schrier et al., 1996; Song et al., 2005).

In 12-week glucose-fed rats, $B_{1}$ receptor mRNA and $B_{1}$ receptor binding sites were significantly increased in the spinal cord and several peripheral tissues (aorta, liver, lung, kidney) (Lungu et al., 2007). $\alpha$-Lipoic acid (thioctic acid), a radical scavenger and powerful antioxidant (Packer et al., 2001), prevented or attenuated the development of arterial hypertension, allodynia, the upregulation of $\mathrm{B}_{1}$ receptors, insulin resistance, hyperglycemia, hyperinsulinemia and the oxidative stress in the heart and aorta in glucose-fed rats (El Midaoui and de Champlain, 2002; El Midaoui et al., 2003, 2005; Lungu et al., 2007). These data highlight a possible link between oxidative stress, the induction of $\mathrm{B}_{1}$ receptors and the development of sensory abnormalities.

The original observation regarding the inhibition of allodynia by SSR240612 in this model of insulin resistance is consistent with the acute inhibitory effects of peptide $B_{1}$ receptor antagonists on tactile allodynia and mechanical hyperalgesia in various animal models of nerve injury and persistent inflammation (Perkins et al., 1993; Davis and Perkins, 1994; Bélichard et al., 2000; Fox et al., 2003; Yamaguchi-Sase et al., 2003; Calixto et al., 2004; Ferreira et al., 2005). Although the cellular mechanism by which SSR240612 inhibits allodynia is still unknown, it could not simply reflect a correction of pancreatic function or an antioxidative property of SSR240612 because the higher plasma levels of glucose and insulin, insulin resistance and the higher production of vascular superoxide anion remained unaffected by the dose of SSR240612 $\left(10 \mathrm{mg} \mathrm{kg}^{-1}\right)$, which caused significant inhibition of allodynia. This supports a direct inhibition of $\mathrm{B}_{1}$ receptors affecting spinal cord and/or sensory nerve excitation.

Thermal hyperalgesia was inhibited by peptide $B_{1}$ receptor antagonists in experimental rodent models of type I and type II diabetes (Gabra et al., 2006) and was absent in streptozotocin-induced type $\mathrm{I}$ diabetic $\mathrm{B}_{1}$ receptor knock-out mice (Gabra et al., 2005). The thermal nociceptive threshold was not affected in glucose-fed rats using the plantar heat stimulation, which confirms a previous study using the tail-flick test in the same experimental model (Lungu et al., 2007). Thermal hyperalgesia is mediated by myelinated $\mathrm{A} \delta$ and unmyelinated primary afferent neurons, which include both peptidergic and non peptidergic C-fibres (Handwerker and Kobal, 1993; Yeomans and Proudfit, 1996). Whereas
C-fibres are thought to be involved in the transmission of warm sensations, $\mathrm{A} \delta$-fibres are stimulated by cold stimulus (Pierau and Wurster, 1981). On the contrary, tactile allodynia is a central phenomenon mediated by large myelinated $\mathrm{A} \beta$ fibres (Woolf et al., 1992; Shortland et al., 1997; Pitcher and Henry, 2000). Thus, sensory abnormalities measured in glucose-fed rats which is primarily a non-genetic model of insulin resistance may affect sensory $\mathrm{A} \beta$ and $\mathrm{A} \delta$ fibres but not polymodal C-fibres, at least in the early stages of the disease. This statement is supported by personal unpublished findings showing that the destruction of afferent C-fibres with capsaicin in neonates had no impact on the development of arterial hypertension and cold/tactile allodynia in adult glucose-fed rats. It is also worth noting that capsaicinsensitive C-fibres are not required in the development of tactile allodynia in the rat model of diabetes induced by streptozotocin (Khan et al., 2002). The fact that afferent C-fibres are unlikely to be affected in our pre-diabetic model of insulin resistance may also account for the lack of thermal hypoalgesia that occurs in prolonged diabetic neuropathy (Calcutt et al., 1998, 2004). Transient thermal hyperalgesia and subsequent progressive thermal hypoalgesia occur in diabetic rats secondary to exaggerated flux through the polyol pathway that leads to depletion of ciliary neurotrophic factor (Calcutt et al., 2004). Nitrosative stress, increased aldose reductase activity and the loss of intraepidermal nerve fibres were also found to contribute to thermal hypoalgesia during the progression of the disease (Drel et al., 2006; Vareniuk et al., 2007). Thus, small sensory nerve fibre degeneration, the metabolic and neurotrophic abnormalities associated with thermal hypoalgesia are unlikely to occur in our model of insulin resistance.

\section{Conclusion}

The present findings provide the first pharmacological evidence that the inducible $B_{1}$ receptor is involved in tactile and cold allodynia occurring in chronically glucose-fed rats, an experimental model of insulin resistance. Therefore, selective kinin $B_{1}$ receptor antagonists, especially the new orally active non-peptide antagonist SSR240612, might represent drugs of potential interest for the treatment of sensory polyneuropathy.

\section{Acknowledgements}

This work was supported by grant-in-aids from the Canadian Diabetes Association and Sanofi-Aventis R\&D, France. MAI holds a Studentship from the Government of Libya. 


\section{Conflict of interest}

The authors state no conflict of interest.

\section{References}

Abdouh M, Khanjari A, Abdelazziz N, Ongali B, Couture R, Hassessian HM (2003). Early upregulation of kinin $B_{1}$ receptors in retinal microvessels of the streptozotocin-diabetic rat. Br J Pharmacol 140: 33-40.

Bélichard P, Landry M, Faye P, Bachvarov DR, Bouthillier J, Pruneau D et al. (2000). Inflammatory hyperalgesia induced by zymosan in the plantar tissue of the rat: effect of kinin receptor antagonists. Immunopharmacology 46: 139-147.

Calcutt NA, Dines KC, Ceseña RM (1998). Effects of the peptide HP228 on nerve disorders in diabetic rats. Metabolism 47: 650-656.

Calcutt NA, Freshwater JD, Mizisin AP (2004). Prevention of sensory disorders in diabetic Sprague-Dawley rats by aldose reductase inhibition or treatment with ciliary neurotrophic factor. Diabetologia 47: 718-724.

Calixto JB, Medeiros R, Fernandes ES, Ferreira J, Cabrini DA, Campos MM (2004). Kinin $B_{1}$ receptors: key G-protein-coupled receptors and their role in inflammatory and painful processes. Review. Br J Pharmacol 143: 803-818.

Campos MM, Cabrini DA, Cardozo AHM, Rae GA, Toro JPH, Calixto JB (2001). Changes in paw oedema triggered via bradykinin $B_{1}$ and $\mathrm{B}_{2}$ receptors in streptozotocin-diabetic rats. Eur J Pharmacol 416: 169-177.

Campos MM, Ongali B, De Souza Buck H, Schanstra JP, Girolami JP, Chabot JG et al. (2005). Expression and distribution of kinin $\mathrm{B}_{1}$ receptor in the rat brain and alterations induced by diabetes in the model of streptozotocin. Synapse 57: 29-37.

Chaplan SR, Bach FW, Pogrel JW, Chung JM, Yaksh TL (1994). Quantitative assessment of tactile allodynia in the rat paw. J Neurosci Methods 53: 55-63.

Choi Y, Yoon YW, Na HS, Park MJ, Chung JM (1994). Behavioral signs of ongoing pain and cold allodynia in a rat model of neuropathic pain. Pain 59: 369-376.

Cloutier F, Couture R (2000). Pharmacological characterization of the cardiovascular responses elicited by kinin $\mathrm{B}_{1}$ and $\mathrm{B}_{2}$ receptor agonists in the spinal cord of streptozotocin-diabetic rats. Br J Pharmacol 130: 375-385.

Couture R, Girolami JP (2004). Putative roles of kinin receptors in the therapeutic effects of angiotensin 1-converting enzyme inhibitors in diabetes mellitus. Eur J Pharmacol 500: 467-485.

Couture R, Harrisson M, Vianna RM, Cloutier F (2001). Kinin receptors in pain and inflammation. Eur J Pharmacol 429: 161-176.

Couture R, Lindsey CJ (2000). Brain kallikrein-kinin system: from receptors to neuronal pathways and physiological functions. In: Quirion R, Björklund A, Hökfelt Th (eds). Handbook of Chemical Neuroanatomy, Peptide Receptors, Part 1, vol 16. Elsevier Science BV: Amsterdam, The Netherlands, pp 241-300.

Dai S, McNeill JH (1995). Fructose-induced hypertension in rats is concentration- and duration-dependent. J Pharmacol Toxicol Methods 33: 101-107.

Davis AJ, Perkins MN (1994). Induction of $B_{1}$ receptors in vivo in a model of persistent inflammatory mechanical hyperalgesia in the rat. Neuropharmacology 33: 127-133.

Deblois D, Horlick RA (2001). Endotoxin sensitization to kinin $B_{1}$ receptor agonist in a non-human primate model: haemodynamic and pro-inflammatory effects. Br J Pharmacol 132: 327-335.

Drel VR, Mashtalir N, Ilnytska O, Shin J, Li F, Lyzogubov VV et al. (2006). The leptin-deficient (ob/ob) mouse: a new animal model of peripheral neuropathy of type 2 diabetes and obesity. Diabetes 55: 3335-3343.

El Midaoui A, de Champlain J (2002). Prevention of hypertension, insulin resistance, and oxidative stress by alpha-lipoic acid. Hypertension 39: 303-307.

El Midaoui A, de Champlain J (2005). Effects of glucose and insulin on the development of oxidative stress and hypertension in animal models of type 1 and type 2 diabetes. J Hypertens 23: 581-588.
El Midaoui A, Elimadi A, Wu L, Haddad PS, de Champlain J (2003). Lipoic acid prevents hypertension, hyperglycemia, and the increase in heart mitochondrial superoxide production. $\mathrm{Am}$ Hypertens 16: 173-179.

El Midaoui A, Ongali B, Petcu M, Rodi D, de Champlain J, Neugebauer $\mathrm{W}$ et al. (2005). Increases of spinal kinin receptor binding sites in two rat models of insulin resistance. Peptides 26: 1323-1330.

Feldman EL (2003). Oxidative stress and diabetic neuropathy: a new understanding of an old problem. J Clin Invest 111: 431-433.

Ferreira J, Beirith A, Mori MAS, Araujo RC, Bader M, Pesquero JB et al. (2005). Reduced nerve injury-induced neuropathic pain in kinin $\mathrm{B}_{1}$ receptor knock-out mice. I Neurosci 25: 2405-2412.

Fox A, Wotherspoon G, McNair K, Hudson L, Patel S, Gentry C et al. (2003). Regulation and function of spinal and peripheral neuronal $\mathrm{B}_{1}$ bradykinin receptors in inflammatory mechanical hyperalgesia. Pain 104: 683-691.

Gabra BH, Berthiaume N, Sirois P, Nantel F, Battistini B (2006). The kinin system mediates hyperalgesia through the inducible bradykinin $B_{1}$ receptor subtype: evidence in various experimental animal models of type 1 and type 2 diabetic neuropathy. Biol Chem 387: 127-143.

Gabra BH, Merino VF, Bader M, Pesquero JB, Sirois P (2005). Absence of diabetic hyperalgesia in bradykinin $\mathrm{B}_{1}$ receptor-knockout mice. Regul Peptides 127: 245-248.

Gabra BH, Sirois P (2003). Beneficial effect of chronic treatment with the selective bradykinin $\mathrm{B}_{1}$ receptor antagonists, R-715 and R-954, in attenuating streptozotocin-diabetic thermal hyperalgesia in mice. Peptides 24: 1131-1139.

Gorus FK, Weets I, Couck P, Pipeleers D (2004). Epidemiology of type 1 and type 2 diabetes. The added value of diabetes registries for conducting clinical studies: the Belgian paradigm. Acta Clin Belg 59: 1-13.

Gougat J, Ferrari B, Sarran L, Planchenault C, Poncelet M, Maruani J et al. (2004). SSR240612 [(2R)-2-[((3R)-3-(1, 3-Benzodioxol-5-yl)-3$\{[(6-m e t h o x y-2$-naphthyl)sulfonyl]amino\}propanoyl)amino]-3-(4-\{[2R, 6S)-2, 6-dimethylpiperidinyl]methyl phenyl)- $\mathrm{N}$-isopropyl- $\mathrm{N}$-methylpropanamide hydrochloride], a new nonpeptide antagonist of the bradykinin $B_{1}$ receptor: biochemical and pharmacological characterization. J Pharmacol Exp Ther 309: 661-669.

Handwerker HO, Kobal G (1993). Psychophysiology of experimentally induced pain. Physiol Rev 73: 639-671.

Hargreaves K, Dubner R, Brown F, Flores C, Joris J (1988). A new and sensitive method for measuring thermal nociception in cutaneous hyperalgesia. Pain 32: 77-88.

Hwang IS, Ho H, Hoffman BB, Reaven GM (1987). Fructose-induced insulin resistance and hypertension in rats. Hypertension 10: 512-516.

Khan GM, Chen SR, Pan HL (2002). Role of primary afferent nerves in allodynia caused by diabetic neuropathy in rats. Neuroscience 114: 291-299.

King H, Aubert RE, Herman WH (1998). Global burden of diabetes, 1995-2025: prevalence, numerical estimates, and projections. Diabetes Care 21: 1414-1431.

Lawson SR, Gabra BH, Guérin B, Neugebauer W, Nantel F, Battistini B et al. (2005). Enhanced dermal and retinal vascular permeability in streptozotocin-induced type 1 diabetes in Wistar rats: blockade with a selective bradykinin B1 receptor antagonist. Regul Pept 124: 221-224.

Lungu C, Dias JP, Estevao de França C, Ongali B, Regoli D, Moldovan $\mathrm{F}$ et al. (2007). Involvement of kinin $\mathrm{B}_{1}$ receptor and oxidative stress in sensory abnormalities and arterial hypertension in an experimental rat model of insulin resistance. Neuropeptides (in revision)

Mage M, Pécher C, Neau E, Cellier E, Dos Reiss ML, Schanstra JP et al. (2002). Induction of B1 receptors in streptozotocin diabetic rats: possible involvement in the control of hyperglycemia-induced glomerular Erk 1 and 2 phosphorylation. Can J Physiol Pharmacol 80: $328-333$

Marceau F, Hess JF, Bachvarov DR (1998). The $B_{1}$ receptors for kinins Pharmacol Rev 50: 357-386.

Matthews DR, Hosker JP, Rudenski AS, Naylor BA, Treacher DF, Turner RC (1985). Homeostasis model assessment: insulin resistance and $\beta$-cell function from fasting plasma glucose and insulin concentrations in man. Diabetologia 28: 412-419. 
Munzel T, Sayegh H, Freeman BA, Tarpey MM, Harrison DG (1995). Evidence for enhanced vascular superoxide anion production in nitrate tolerance. A novel mechanism underlying tolerance and cross-tolerance. J Clin Invest 95: 187-194.

Ongali B, Campos MM, Petcu M, Rodi D, Cloutier F, Chabot JG et al. (2004). Expression of kinin B1 receptors in the spinal cord of streptozotocin-diabetic rat. Neuroreport 15: 2463-2466.

Packer L, Kraemer K, Rimbach G (2001). Molecular aspects of lipoic acid in the prevention of diabetes complications. Nutrition 17: 888-895.

Perkins MN, Campbell E, Dray A (1993). Antinociceptive activity of the bradykinin $\mathrm{B}_{1}$ and $\mathrm{B}_{2}$ receptor antagonists, des-Arg ${ }^{9}$, [Leu $\left.{ }^{8}\right]$-BK and HOE 140, in two models of persistent hyperalgesia in the rat. Pain 53: 191-197.

Pierau FK, Wurster RD (1981). Primary afferent input from cutaneous thermoreceptors. Fed Proc 40: 2819-2824.

Pitcher GM, Henry JL (2000). Cellular mechanisms of hyperalgesia and spontaneous pain in a spinalized rat model of peripheral neuropathy: changes in myelinated afferent inputs implicated. Eur J Neurosci 12: 2006-2020.

Regoli D, Nsa Allogho S, Rizzi A, Gobeil FJ (1998). Bradykinin receptors and their antagonists. Eur J Pharmacol 348: 1-10.

Schrier RW, Estacio RO, Jeffers B (1996). Appropriate Blood Pressure Control in NIDDM (ABCD) Trial. Diabetologia 39: 1646-1654.

Shortland P, Kinman E, Molander C (1997). Sprouting of A-fibre primary afferents into lamina II in two rat models of neuropathic pain. Eur J Pain 1: 215-227.
Simard B, Gabra BH, Sirois P (2002). Inhibitory effect of a novel bradykinin $B_{1}$ receptor antagonist, R-954, on enhanced vascular permeability in type 1 diabetic mice. Can J Physiol Pharmacol 80: 1203-1207.

Song D, Hutchings S, Pang CCY (2005). Chronic N-acetylcysteine prevents fructose-induced insulin resistance and hypertension in rats. Eur J Pharmacol 508: 205-210.

Thorell JI, Lanner A (1973). Influence of heparin-plasma, EDTAplasma, and serum on the determination of insulin with three different radioimmunoassays. Scand J Clin Lab Invest 31: 187-190.

Vareniuk I, Pavlov IA, Drel VR, Lyzogubov VV, Ilnytska O, Bell SR et al. (2007). Nitrosative stress and peripheral diabetic-neuropathy in leptin-deficient (ob/ob) mice. Exp Neurol 205: 425-436.

Woolf CJ, Shortland P, Coggeshall RE (1992). Peripheral nerve injury triggers central sprouting of myelinated afferents. Nature 355: 75-78.

Yamaguchi-Sase S, Hayashi I, Okamoto H, Nara Y, Matsuzaki S, Hoka S et al. (2003). Amelioration of hyperalgesia by kinin receptor antagonists or kininogen deficiency in chronic constriction nerve injury in rats. Inflamm Res 52: 164-169.

Yeomans DC, Proudfit HK (1996). Nociceptive responses to high and low rates of noxious cutaneous heating are mediated by different nociceptors in the rat: electrophysiological evidence. Pain 68 : 141-150.

Zimmet P (2003). The burden of type 2 diabetes: are we doing enough? Diabetes Metab 29 (4 Pt): 6S9-6S18. 